\title{
Analytical modeling of the backfill massif deformations around the chamber with mining depth increase
}

\author{
O. Khomenko, M. Kononenko \& M. Petlovanyi \\ National Mining University, Dnipropetrovsk, Ukraine
}

\begin{abstract}
Using thermodynamic analytical research method, the investigation of strains formation in the backfill massif around the chamber of second stage was performed. It was established that the horizontal and vertical dimensions of areas vary with increasing deformation depth of the development by logarithmic and exponential law with relevant empirical equations.
\end{abstract}

\section{INTRODUCTION}

During the development of steeply dipping ore deposits using chamber systems with solid backfill the quality of extracted minerals is determined by the stability of backfilling mass. Use the chamber mining with a solid backfill mainly carried out on the "chamber-pillar" method with the mining from the center of the mine field to its flanks. The technology of mining involves practicing inter-chamber ore pillars in the second stage, which are located near artificial rock massif. With this order of ore deposits mining, there is contamination of ore with waste rock and contaminated backfill. Contaminated ore with collapsed backfill causes significant harm to the economic activity of the enterprise, manifested in the reduction of product quality and technical and economic performance. For example, getting only $1 \%$ of the backfill material in the ore is accompanied with decrease value $1.7-2 \%$ (Kuzmenko et al. 2014).

Deformation characteristics of backfill significantly inferior ore-rock massif, so the increased concentration of the stress increases with mining depth increase that contributes the collapse and fall out of rock massif (Falshtynskyy et al. 2012, Falshtynskyi et al. 2013). In this regard, the assessment of deformations occurring in backfilling mass adjacent to the mining chambers by increasing the depth of the development is an important scientific and practical problem, the solution of which will allow forecasting the stability of artificial rock massif.

\section{THE MAIN PART OF THE ARTICLE}

The object of the research is the technology of mining in Pivdenno-Bilozerske rich iron ore deposit, which is developing by Private Joint Stock Compa- ny "Zaporizhskyi iron ore plant" (PJSC "ZIOP") using the chamber system development with solid backfilling. Developed and implemented recommendations of Mining Research Institute of State Higher Educational Institution "National Kryvyi Rih University" a new form of chambers for the conditions of the Pivdenno-Bilozerske deposits has reduced the amount of roadway construction and the time of delivery equipment in blocks. This has been achieved through the formation of a high sloping rock at the bottom of the hanging wall deposits. Changing the system design development led to intensification of rock pressure increase on the contours of the working space, where there are rock inrush, adjacent strata and backfill.

The research of destructive strains that have been developed in adjacent strata of backfill massif around chambers of second stages was examined. This is due to the fact that at the location of chambers on the second stage of contact with hanging wall rocks, the influence of the space and time factor of their exposure to the stability of the rock massif, so the impact of backfilling in this case is very difficult.

Contamination of ore during ore extraction in the footwall has an extraordinary character (Kuzmenko 2014). During iron ore extraction in the chamber of the first stage contamination of ore makes up to $0.5-1.8 \%$ of the rock. Then from chambers of the second stage such indicators make up to $3-5.1 \%$ of the rock. This confirms the negative impact of backfilling mass during mining of chamber stock in contact with the footwall side of rocks. Increased ore contamination is the result of complex geomechanical processes occurring in the rock massif, consisting of ore, adjacent strata and backfill. Establishing of contamination character is necessary for the production of the cutter-loader and in general for mining science. Similar studies have been carried 
out previously for mining ore deposit for the floor of $940-1040 \mathrm{~m}$ (Khomenko et al. 2014), but in this paper we consider the change of destructive strains with mining depth increase.

Under condition of Pivdenno-Bilozerske deposit physical-mechanical properties of ore, rocks and backfill are represented in a wide range. Strength of ores ranges from 60 to $80 \mathrm{MPa}$, the adjacent strata $80-140 \mathrm{MPa}$, backfill $50-60 \mathrm{MPa}$ (by a factor of stability). Bulk weight of ore is $0.39-0.4 \mathrm{MN} / \mathrm{m}^{3}$ and adjacent rocks varies from 0.21 to $0.29 \mathrm{MN} / \mathrm{m}^{3}$. The strength of rocks and backfill significantly affect the rock massif deformation around the chamber of the second stage. To assess the spread of strain fields around the extraction chamber in the rock massif was selected one of the modern analytical method. Analysis of theoretical research methods allowed us to determine the most appropriate method - thermodynamic (Lavrinenko \& Lisak 1993), which gives the highest accuracy of $(85-90 \%)$ calculated and directly measured elastic deformations.

Assess the impact of destructive deformations on backfilling massif formed in the zone of chambers influence is possible with mining depth increase (Lozynskyi et al. 2015). Ore extraction in footwall chambers surrounded backfilling massif strike on ore deposit shows a wide variation of contamination indicators from 2 to $7 \%$. This is due to the variety of influencing factors such as hardness of rocks, fracturing, area and the time of exposure, varying elements of the block parameters (height, width, length of the chamber). Therefore, to determine the influence of mining depth is useful to consider ore contamination during mining with the same chamber parameters for a particular area of the deposit. For this we consider abandoned place $-4 \mathrm{~s}$ deposits at a depth of $465-$ $840 \mathrm{~m}$, chamber $1 / 4 \mathrm{~s}$ (level $465-580 \mathrm{~m}$ ), 1/4s (level $548-640 \mathrm{~m}$ ), 2/4s (level $640-740 \mathrm{~m}$ ) 1/4s (level $740-840 \mathrm{~m}$ ) with an average chamber parameters: height -110 meters, width $-30 \mathrm{~m}$, length $-45 \mathrm{~m}$. Ore contamination indicators and volume of reserves are shown in Table 1. According to the data presented in Table 1 was plotted diagram (Figure 1) the influence of mining depth to backfill collapse during ore extraction along the axis $4 \mathrm{~s}$.

Table 1. Contamination of ore extracted in second stage chamber along the axis $4 \mathrm{~s}$.

\begin{tabular}{cccc}
\hline Chamber & Level, $\mathrm{m}$ & $\begin{array}{c}\text { Reserves in } \\
\text { chamber, } \\
\text { thousand tons }\end{array}$ & $\begin{array}{c}\text { Contamination of } \\
\text { ore, thousand } \\
\text { tons } / \%\end{array}$ \\
\hline $1 / 4 \mathrm{~s}$ & $465-580$ & 323 & $7.9 / 2.47$ \\
$1 / 4 \mathrm{~s}$ & $548-640$ & 313 & $13.2 / 4.23$ \\
$2 / 4 \mathrm{~s}$ & $640-740$ & 303 & $16.6 / 5.55$ \\
$1 / 4 \mathrm{~s}$ & $740-840$ & 590 & $18.6 / 3.16$ \\
\hline
\end{tabular}

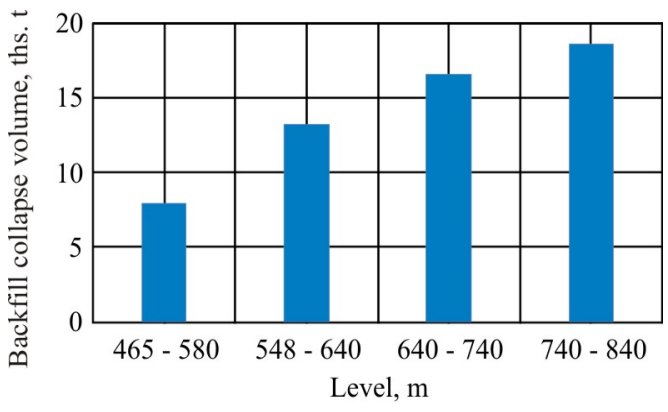

Figure 1. Influence of mining depth to backfill collapse during ore extraction along the axis $4 \mathrm{~s}$.

From Figure 1 is shown that there is correlation between the depth and the volume of backfill massif caving in the working chamber. The trend shows that with mining depth increase from 465 to $840 \mathrm{~m}$ volumes of caving increased by 2.3 times. For more reliable results need to be exploring more of the number of chambers located in different axes along the strike of the deposit. The aim of further research is the study of the nature of destructive deformations in the rock massif surrounding ore reserves in the chamber of the second stage with mining depth increase. Main objectives of the analytical modeling are: the study of destructive deformations areas around the secondary chamber; the influence of the depth of the secondary chamber on the rock massif; to identify the law of destructive deformation changes in the rock massif.

Increasing the depth of the chamber is accompanied by an increase in the destressed zone and rising tensions of surrounding rocks. Deformation occurs in places where the real stress arising within rock massif destressed zone, exceed the maximum allowable tensile or shear. The difference between the current and ultimate strain reflects the safety factor. For the same geological conditions analytical modeling of the influence of second stage chamber on the rock massif and backfill was made to the depth of exploitation 840 $1040 \mathrm{~m}$. As an example, we saw the formation of deformation areas in the rock massif and backfill of the second stage chamber, located across the strike of the deposit at different laying depth (Figure 2).

Figure 2 shows that the area of backfill deformation around the second stage chamber across the strike of the deposit becoming elongated shape resembling an ellipse and arranged in a backfill massif of the primary chamber and the chamber roof. On $2 / 3$ the height of the chamber in backfill massif of the primary chamber, the deformation area with increasing depth of the chamber from 840 to $1040 \mathrm{~m}$ spreading towards the rock outcrop hanging wall at a distance of $27-30 \mathrm{~m}$. 
(a)

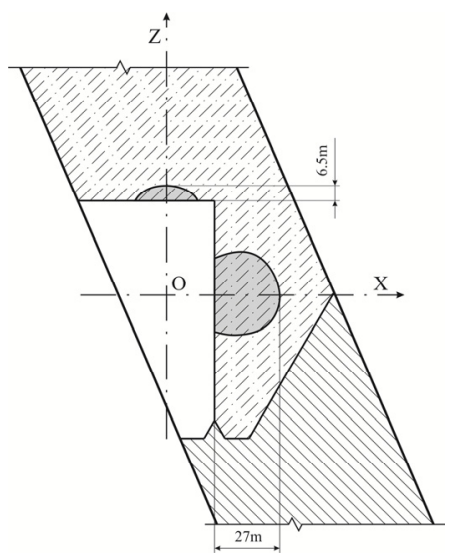

(b)

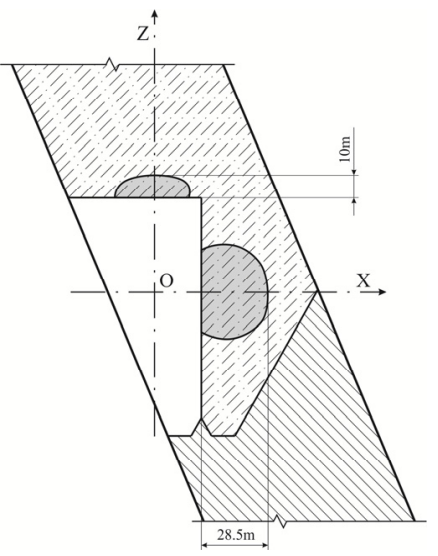

(c)

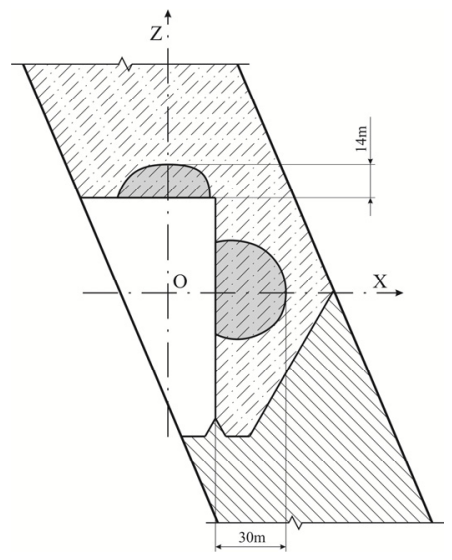

Figure 2. Formation areas of possible destructive strains in the unloading area of second stage chambers across the strike of the deposit at a depth of their location: (a) $840 \mathrm{~m}$; (b) $940 \mathrm{~m}$; (c) $1040 \mathrm{~m}$.
The width of this strain region increased from $30-35 \mathrm{~m}$ up to $38-42 \mathrm{~m}$ and has an effect on the power required reinforcement layer of backfill. In the roof of the chamber, at a depth of $840 \mathrm{~m}$ of mining operations in backfill massif of overlaying layer, the deformation extends to the height of $6.5 \mathrm{~m}$. With depth increase of the chamber to $1040 \mathrm{~m}$, the area of deformation increases up to 14 meters. The width of this area with mining depth increase from 840 to $1040 \mathrm{~m}$ increases from $20-26 \mathrm{~m}$ to $27-32 \mathrm{~m}$. It should be noted that the destruction of the roof and the chamber is more likely caused by the gravitation forces, while caving out of the chamber sides occur in its path. At the same time, in the depth of the backfill massif occurs fracturing and discontinuity.

Gross findings of the stress-deformed state of the backfill massif can be seen from changes of areas of possible destructive strains (Figure 3).

(a)

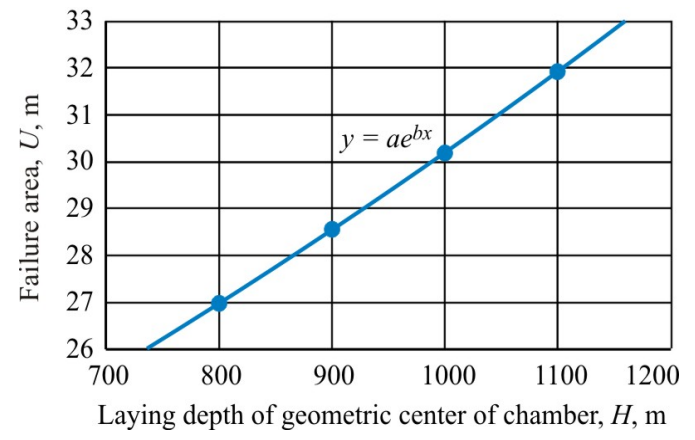

(b)

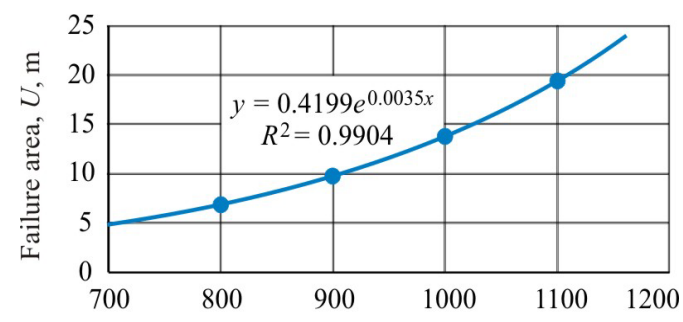

Laying depth of geometric center of chamber, $H, \mathrm{~m}$

Figure 3. Change of failure area in the backfill massif in chambers of the first stage (a) and in the top of chambers of the second stage (b) with mining depth increase.

After approximation of the maximum values using Microsoft Excel 2013 empirical law equations of the failure area value $U$ on depth $H$ was obtained. For the backfill massif, surrounding secondary chamber along the strike of deposits the empirical law is written as: 
- failure area in backfill massif of the first stage chamber mining:

$$
U=17.2 \cdot e^{0.0006 \cdot H}, \mathrm{~m}, R^{2}=0.9974,
$$

where $H$-depth of the geometric center of the chamber, $\mathrm{m} ; R$ - authenticity of approximation.

- failure area in backfill massif in roof rocks of the second stage chamber mining:

$$
U=0.42 \cdot e^{0.0035 \cdot H}, \mathrm{~m}, R^{2}=0.9904 \text {. }
$$

As an example the formation of strain fields in the backfill massif, surrounding chambers of the second stage located along the strike of the deposit at different laying depth (Figure 4).
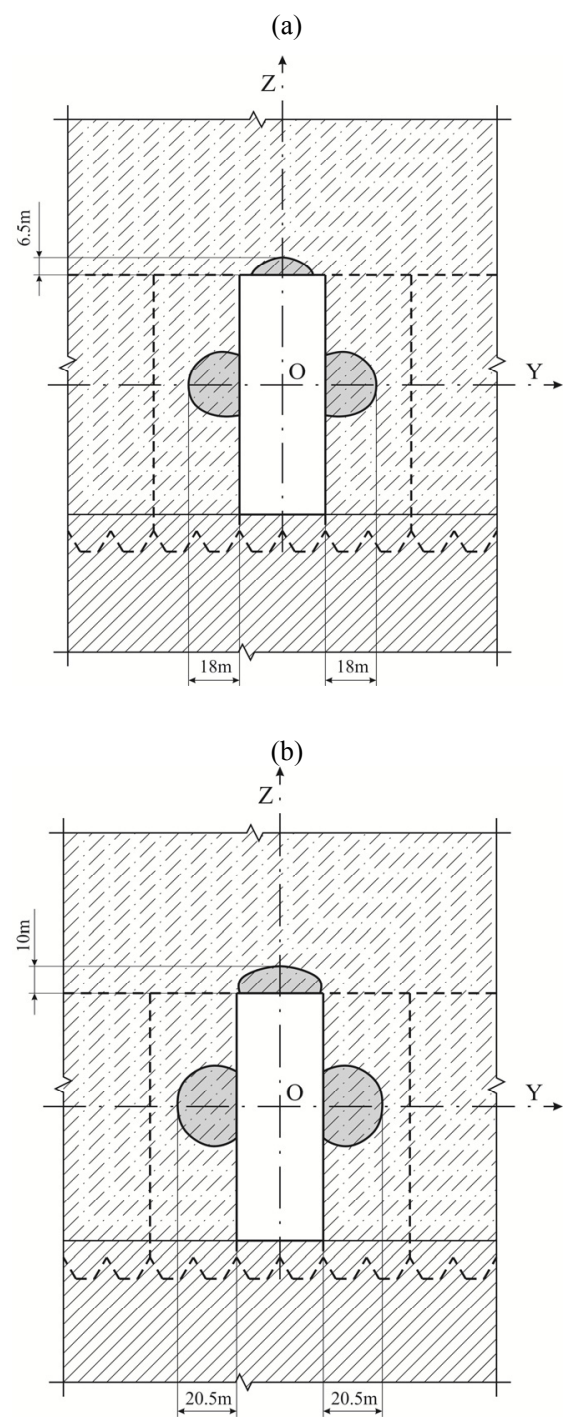

(c)

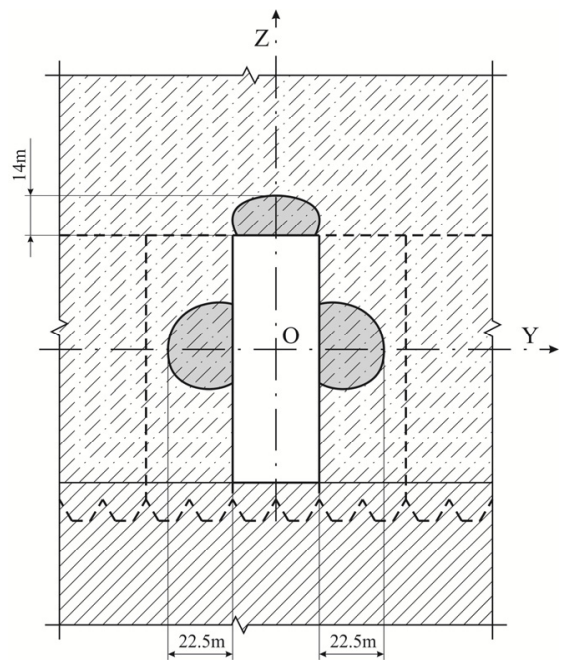

Figure 4. Formation of the failure area around the chambers of the second stage located along the strike of the deposit at a depth of: (a) $840 \mathrm{~m}$; (b) $940 \mathrm{~m}$; (c) $1040 \mathrm{~m}$.

Figure 4 clearly shows that the area of backfill massif deformation around the chamber has an elongated shape resembling an ellipse and arranged in sides of the chamber. On $2 / 3$ the height of the chamber the deformation area with increasing depth of the chamber from 840 to $1040 \mathrm{~m}$ spreading towards the rock outcrop at a distance of $18-22.5 \mathrm{~m}$. The width of this strain region increased from 20 $25 \mathrm{~m}$ up to $28-31$

Changes in the stress-strain state in the backfill massif of chambers of the second stage, which are located along the strike of the deposit with mining depth increase, can be observed on areas of possible destructive strains (Figure 5).

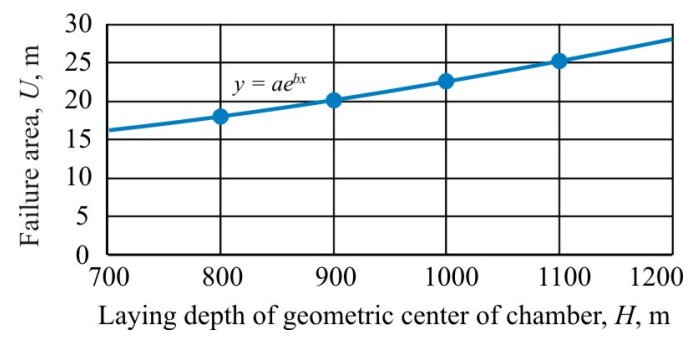

Figure 5. Change of the failure area in the backfill massif in chambers of the first stage located at sides of chambers of the second stage with mining depth increase.

After approximation of the maximum values using Microsoft Excel 2013 empirical law equations of the failure area value $U$ on depth $H$ was obtained. For 
backfill massif, surrounding secondary chamber along the strike of deposits the empirical law is written as:

$U=7.7 \cdot e^{0.0011 \cdot H}, \mathrm{~m}, R^{2}=0.9953$.

Further studies will allow changes in width of the failure area in backfill massif in the chamber of second stage with mining depth increase (Figure 6).

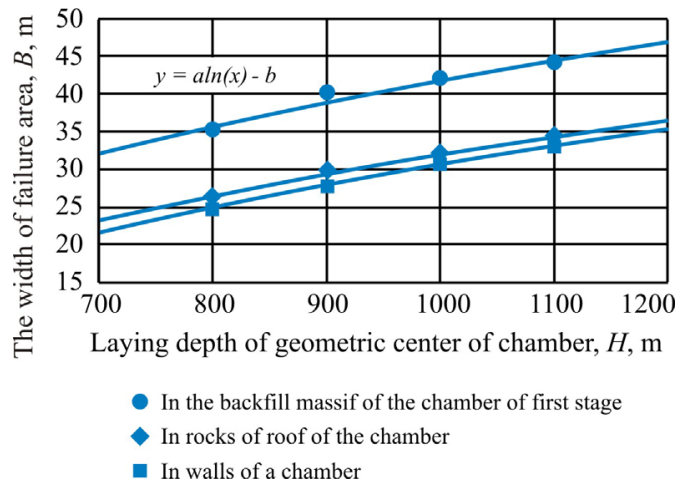

Figure 6. Change of the width of failure area in the backfill massif in chambers of the second stage with mining depth increase.

After approximation of the maximum values using Microsoft Excel 2013 empirical law equations of the failure area value $U$ on depth $B$ was obtained. For the backfill massif, surrounding secondary chamber along the strike of deposits the empirical law is written as:

- failure area in the backfill massif of the first stage chamber mining:

$B=27.6 \cdot \ln (H)-148.7, \mathrm{~m}, R^{2}=0.9587$;

- failure area in the backfill massif in rocks of the roof of second stage chamber mining:

$B=24.7 \cdot \ln (H)-138.4, \mathrm{~m}, R^{2}=0.9796$;

- failure area in the backfill massif in rocks of a workings of the second stage chamber mining:

$B=25.5 \cdot \ln (H)-145.4, \mathrm{~m}, R^{2}=0.9972$.

Research results of conducted investigation in the context of failure area in the backfill massif around the chamber of second stage with mining depth increase can be described by the exponential law and its width by the logarithmic law. This empirical law of the deformation and its width for different mining laying depths allow defining the size and shape of the failure area, which significantly affect the stability of backfilling massif in chambers. The studies confirm the importance of mining in the areas of destructive deformations that must be followed with accurate backfilling massif deformation.

\section{CONCLUSIONS}

During the chamber mining with a hardening backfill with mining depth increase by 1.6 times the volume of backfill massif caving on the contour of the second stage chamber mining increased by 2.3 times. Analysis of the caving formation should be carried out down-dip of ore deposits by ones geological section.

The size of failure deformations in the backfill massif in the chamber of first stage, as well as sides and roof of the second stage chamber exponentially depend on the mining depth. The most intense deformations developed in roof rocks of the chamber, with mining depth increase by 1.6 times. Their value increased by 2.1 times, and in the backfilling massif in chambers of the first stage and the sides of the chambers of second stage only by $1.1-1.2$ times.

With mining depth increase the width of failure area develops more intense than in the horizontal plane by 1.3 times and change by logarithmic law, which leads to additional costs for forming the hardened backfill layer.

\section{REFERENCES}

Khomenko, O., Kononenko, M. \& Petlyovanyy, M. 2014. Investigation of the stress-strain state of the rock massif around secondary chambers. Progressive Technologies of Coal, Coalbed Methane, and Ores Mining. The Netherlands: CRC Press/ Balkema: $241-245$.

Kuzmenko, A. Petlyovanyy, M \& Heylo, A. 2014. Application of fine-grained binding materials in the technology of hardening backfill construction. Progressive Technologies of Coal, Coalbed Methane, and Ores Mining. The Netherlands: CRC Press/Balkema: 465 - 469.

Kuzmenko, A.M. 2014. An impact of the structure of the rock massif and the order of chamber mining on ore contamination. Collection of research papers NAS of Ukraine, IGTM, No 118: 37 - 45.

Falshtyns'kyy, V., Dychkovs'kyy, R., Lozyns'kyy, V. \& Saik, P. 2013. Justification of the gasification channel length in underground gas generator. Annual Scientific-Technical Colletion - Mining of Mineral Deposits 2013. The Netherlands: CRC Press/Balkema: 125 - 132.

Falshtynskyy, V., Dychkovskyy, R., Lozynskyy, V. \& Saik, P. 2012. New method for the justification of technological parameters of the coal gasification in the test setting. Geomechanical Processes during Underground Mining Proceedings of the School of Underground Mining. The Netherlands: CRC Press/Balkema: $201-208$.

Lavrinenko, V.F \& Lisak,V.I. 1993. Physical processes in the rock mass in the disequilibrium. News of Higher Educational Institution, Mining journal, No 1: $1-6$.

Lozynskyi, V.G., Dychkovskyi, R.O., Falshtynskyi, V.S., Saik, P.B. 2015. Revisiting possibility to cross the disjunctive geological faults by underground gasifier. Naukovyi Visnyk Natsionalnoho Hirnychoho Universytetu, No 4. 
